\title{
29
}

\section{The Formation of a National Capital Stock and the Pension Systems in South Korea and Malaysia}

\section{Johanna Kuhlmann and Frank Nullmeier}

\section{Introduction}

Old-age provision is a core function of welfare state activity. However, the advantages of establishing a pension scheme are by no means limited to providing for old age. It can also serve other political, societal, or economic functions. In this chapter, we examine such an interdependence of policy areas by illuminating the relationship between expansive social policy and the export strategy of developmental states (Evans and Heller 2015). We start with the case of South Korea, which has developed into one of the leading industrial nations since the Korean War (1950-1953) and the subsequent division of the country. Through a strictly exportoriented economy under state control—initially under a military dictatorship, and since the late 1980s under a presidential democracy-South Korea has become one of the strongest economies in the world. Under the Park military dictatorship, this was accompanied by a renunciation of

J. Kuhlmann $(\square) \bullet$ F. Nullmeier

University of Bremen, Bremen, Germany

e-mail: johanna.kuhlmann@uni-bremen.de; frank.nullmeier@uni-bremen.de

(C) The Author(s) 2022

F. Nullmeier et al. (eds.), International Impacts on Social Policy, Global Dynamics of Social Policy, https://doi.org/10.1007/978-3-030-86645-7_29 
social policy. As part of the country's democratisation at the end of the 1980s, an expansive social policy that included ever larger segments of the population in the social insurance system became an integral part of economic expansion. Today, Korea's pension fund is the third-largest pension fund in the world. Our second case is Malaysia, an upper-middleincome country whose economic success is also strongly linked to its export orientation. In 1951, while still under British colonial rule, the country established a statutory provident fund to provide social protection for private-sector workers. The fund was maintained and expanded throughout the transition and is today among the twenty largest pension funds worldwide. In both countries, the pension fund stabilises large companies, promotes infrastructure, and improves national competitiveness.

\section{The Relationship Between Building National Capital and Providing Social Security}

Lack of capital is one of the major problems in countries with less developed or emerging economies. This problem can be solved by the inflow of international capital. However, such capital inflow can cause countries to become indebted and dependent on transnational companies, banks, or investment funds. Confronted with this problem, establishing a national capital stock becomes an important strategic factor for any form of policy that is aimed at national independence, both economically and politically. One path toward establishing such a capital stock is industrialisation, which is capital intensive by its very nature. To pursue this path, it therefore becomes an attractive option for state elites, who also serve as agents of economic development, to create their own capital base or at least a capital stock that is closely linked to the state apparatus.

This need for independent sources of capital can be linked to the building and expansion of contribution-based pension schemes. If a country introduces a contribution-based pension system that includes large parts of the population, and this system does not strictly operate on a 
pay-as-you-go (PAYG) basis but rather relies to a significant extent on capital funding, this creates enormous assets in the hands of the insurer within a relatively short time. If the insurer is the state, establishing and expanding such a pension system can increase the national capital base, thus indicating that expansive social policy and state-supported economic development go hand in hand. It is in the government's interest to maintain and expand the financial base of the pension scheme, as these funds can be used for different purposes, for example, as part of a strategy to foster the competitiveness of the national economy in international trade. Governments can use different measures to expand the financial base of the pension scheme, such as increasing contribution rates or expanding the group of people that contribute to the scheme. Capital assets increase in particular if contributions have already been paid but no pension payments have yet been made, for example, due to a statutory minimum savings period or waiting period. Whatever the case may be, any breakdown of the pension system is a profoundly unfavourable development, and governments will do their utmost to prevent this.

\section{The Pension Insurance System in South Korea}

Pension policy in South Korea has clearly been driven by such considerations. Today, South Korea has a public old-age insurance scheme that is based on the principle of defined benefits and can be categorised as the Bismarckian type with contributions paid by employers and employees. The country introduced a general public pension scheme at a comparably late stage of its economic development. President Park Chung-hee, the leader of the military regime, announced the introduction of a compulsory national pension system in 1973 but postponed its establishment several times. It was not until 1988, shortly after the country's democratisation, that a general pension insurance scheme was implemented. It was then expanded rather quickly. Under the military dictatorship, the economic status of employees was guaranteed by means of a lifetime employment and seniority wage system. Strikes and a strong opposition 
movement led not only to gradual democratisation but also to a more flexible labour market, for which workers were compensated with social policy measures (Peng 2012). The transition to democracy at the end of the 1980s was therefore closely linked to the expansion of health insurance and old-age pension insurance. This approach to social policy has been part of an economic development strategy that has made South Korea one of the leading industrial nations.

Initially, the compulsory pension insurance scheme only applied to employees in companies with more than ten employees. From 1992 on, it covered all employees in companies with more than five employees. This process of expansion continued in 1995 with the inclusion of the rural self-employed, farmers, and fishermen (2.1 million people; Yang 2017, 121) and again in 1999 with the inclusion of the urban selfemployed. Between 2003 and 2006, coverage was expanded even further to include employees at workplaces with less than five full-time workers. Since 1999, the country's pension law has stipulated that the entire population is to be included in old-age provision at a contribution rate that has now risen to nine percent. Two basic types of mandatory membership exist: one for workplace-based insured persons (contribution shared by the employer and the employee) and one for individually insured persons (contribution completely paid by the insured person), most of whom have to self-report their income. It is also possible for individuals to be insured voluntarily. Exemptions from compulsory insurance are possible in cases of unemployment, business closure, temporary leave, or economic difficulties, as well as for students. In addition to subsidies for farmers and fishermen, subsidies for low-income earners were introduced in 2012 (Duru-Nuri programme) to increase old-age pension coverage. The effect was estimated to be a two percent increase in the number of people insured after four years (Yoo, Kang, and Choi 2016). Since the coverage rate among people under thirty-five years of age is very low and has even fallen, extending the subsidy to additional population groups is currently being discussed. When it comes to the system's performance, the proportion of insured individuals who have actually paid insurance contributions remained at 68.2 percent of the economically active population between eighteen and fifty-nine years of age (Young et al. 2016), 
which is low compared to the long-term OECD member states but quite high compared to other Asian pension systems (Hujo and Cook 2012).

The system has not been very successful in terms of effective coverage and poverty prevention in old age. Although the strategy of involving more and more population groups has been maintained despite problems with its implementation, significant non-compliance on the part of employers, low-wage earners, and the self-employed has thus far made it impossible to create an effective universalist system (Moon, 2012). Moreover, one-quarter to one-third of the insured population make extensive use of exemption criteria and do so over longer periods of time (Moon 2015). As a result of low benefit pay-outs, 43.8 percent of older people (sixty-five+) live in poverty (OECD 2019, 187). Individuals in higher-income professions (Yang 2017, 142) also report significantly lower incomes than they actually earn in an attempt to lower their contribution rates. However, the most pressing problem is that low-income self-employed individuals as well as those in irregular employment do not pay contributions at all.

South Korea's strengthening of civil society organisations and unions as well as the single-member district electoral system after democratisation have certainly contributed to the expansion of old-age provision despite the relatively poor performance of the system and the shortcomings in its implementation. But among the political, economic, and administrative elites, combining social policy with the creation of a national capital stock has played a central role. The development of a capital stock was made possible by one single rule in the pension system: a waiting period before pensions were paid out. In fact, the introduction of the pension insurance system in 1988 was by no means accompanied by a PAYG system. No pension payments were made to people who had already reached retirement age. On the contrary, for twenty years there were only payments into the system. Only then did the earliest wave of employees fulfil the required waiting period. Thus, this provision enabled the state to build a capital stock over twenty years without having to pay out a single pension benefit. The first full pension payments were only made in 2008.

Even before the introduction of the pension insurance system in 1988, the building of capital stock through a funded pension insurance scheme 
played a major role in political decision-making processes (Hwang 2006, 57-64), especially among executives (Kim and Choi 2014) who promoted a welfare state concept that was more focused on economic development than on addressing social problems. Within this framework, social policy was instrumentally oriented towards promoting the national economy. The creation of a pension fund and the long waiting period before pay-outs led to an enormous accumulation of capital, which resulted in a Bismarckian system with capital funding instead of a PAYG system.

The fund continues to be administered autonomously but in close cooperation with the state (Yang 2017, 140). Today, South Korea's National Pension Service is the third-largest pension fund in the world with capital equivalent to 516 billion euros. In the period from 1988 to 2020 , the fund generated an average return on investment of 4.62 percent, with 34.4 percent currently invested in financial assets and development projects outside South Korea. The fund's commitments to social policy are linked to its investment principle of considering the impact on the national economy and financial markets, simply because of the size of the fund (National Pension Service 2020). It owns shares in state-owned companies, is highly involved in the financial sector, and follows a shareholder activism philosophy (Choi et al. 2018). Its importance to the state is therefore extremely high. The fund can support the foreign and financial strategy of the state, even if social policy goals have gained significance over the years.

\section{$4 \quad$ The Employees Provident Fund in Malaysia}

The Employees Provident Fund (EPF) in Malaysia is another example of the close interlinkages between social policy and international economic interdependence. Within the generally fragmented Malaysian pension system (Asher 2012), the EPF is the central institution, and today it is known to be among the oldest provident funds in the world. The EPF is a mandatory defined contribution scheme for private-sector workers (and 
some workers in the public sector not covered by a public sector pension scheme). It is based on fixed employers' and employees' contributions that are accumulated in individual accounts (Asher 2012, 105). While provident funds are thus similar to social insurance systems in that they are linked to employment, they do not run on a PAYG basis and there is no risk pooling. When the EPF was created by the colonial government in 1951, the main rationale was to provide welfare to workers in the private sector through a system that was relatively easy to administer and not overly costly. Clearly, the EPF was initially viewed as a temporary system (McKinnon 1996, 47). However, despite international advice to convert the EPF into a system based on social insurance principles (McKinnon 1996, 48), Malaysia never left the path once adopted, and over the years the EPF continuously expanded to cover all formal private-sector workers. In 1977, the fund was opened to self-employed workers (Employees Provident Fund 2019, 18). In 2016, the EPF was the fifteenth largest pension fund in the world (Price et al. 2018, 7).

The EPF is supervised by the Ministry of Finance and managed by a tripartite governing board (Employees Provident Fund 2019, 18). Each individual member has two accounts, which, respectively, comprise 70 percent (account 1) and 30 percent (account 2) of the contributions. At the age of fifty-five, members can withdraw the accumulated money, and both accounts are merged. From the age of fifty, members can withdraw the money accumulated in account 2. Earlier withdrawal from account 2 is possible for purposes related to housing, education, health needs, or the Islamic pilgrimage to Mecca ( $h a j j)$. Earlier withdrawal from account 1 is also possible for approved investments (Ramesh 2005, 193-94; Price et al. 2018, 15). Members do not have to retire and withdraw the money from the EPF when they turn fifty-five and can instead continue to work and pay contributions.

The monthly contribution rate to the EPF depends on employees' age and income. When the EPF came into being, the total contribution rate was 10 percent, but over the years it gradually increased to become one of the highest contribution rates in the world. In 2018, the general employees' contribution rate was 11 percent, and the employers' contribution rate varied between 12 percent and 13 percent depending on the employees' income. For employees older than sixty, the regular 
contribution rate is halved (Price et al. 2018, 13). It is possible to pay additional voluntary contributions to account 1 . In recent years, the Malaysian government has increased its efforts to open the EPF to all Malaysian citizens, including those who are not in formal employment. As an incentive, people who contribute voluntarily can receive an additional government subsidy to supplement their voluntary contributions (i-Saraan) (Employees Provident Fund 2019; Price et al. 2018).

Current data suggest that roughly half of the labour force is covered by the EPF, which qualifies as more or less universal coverage of formal private-sector workers. Other parts of the formal labour force-for example, civil servants or soldiers - are covered by different schemes. However, with regard to self-employed workers and workers in the large informal sector, there is still a huge coverage gap (Price et al. 2018, 42). Besides these coverage problems, the EPF's capacity to provide social security and therefore prevent poverty among its members in old age has been limited. Replacement rates are low, which is due to the possibility of early withdrawals, many EPF members' low salaries, and the relatively low withdrawal age. While annuities have been possible since 2001, the vast majority of members still prefer lump sum withdrawals, which are often fully exhausted a few years after entering retirement age. Finally, the incapacity of the fund to prevent poverty in old age is due to its design as an individual saving scheme that lacks redistributive elements (Ramesh 2005; Price et al. 2018, 40-43).

Although the EPF was created as a convenient way to provide social security for workers, Malaysian policy actors came to realise that it also provided great opportunities for the country's economic development (Ramesh 2005, 192). A key factor in the important economic role that the EPF plays is that the savings accumulated by the fund can be used by the government for economic purposes. Over the years, EPF balances have grown considerably, from 9.1 billion Malaysian ringgit in 1980 (around 17 percent of gross domestic product [GDP]) to 731.1 billion Malaysian ringgit in 2016 (around 60 percent of GDP) (Asher 2012, 109; Price et al. 2018, 10, 28). In fact, the EPF has been described as an "essentially bottomless source of long-term investment capital with which to finance state-led industrial and infrastructural development" (McKinnon 1996, 50), thus contributing to Malaysia's international 
competitiveness. Infrastructure programmes have been designed to be complementary to private investments, especially in the export-driven manufacturing sector (McKinnon 1996, 56). However, the ways in which the EPF has been used as an "investment bonanza" (McKinnon $1996,50)$ for economic purposes have changed over the years. When the EPF was established, all funds had to be in government securities or bank deposits, and until the 1980s, 80-90 percent of the money from the EPF was in Malaysian government securities. Especially since the 1990s, investment options have been diversified towards a variety of investments, such as privatisation and joint venture projects, equities and debentures of public companies, and the housing market (Ramesh 2005, 203). This diversification strategy not only fuelled the Malaysian capital market but further enabled the financing of large infrastructure projects (Price et al. 2018, 25). In recent years, the EPF has also intensified its investments in foreign markets, resulting in a share of foreign investments of 30 percent in 2017 (compared to only 1 percent in 2006). The rationale behind this new strategy was not only that overseas markets promised solid investments but also that the EPF had become too large for the domestic financial market (Price et al. 2018, 28; see also Asher and Bali 2015). In 2018, the EPF's rate of return on investment was 6.57 percent (Employees Provident Fund 2019, 16).

The EPF's crucial role in Malaysia's economic development is explicitly formulated by the EPF:

In its initial years, the EPF was able to park all of its assets locally in Malaysian Government Securities, Loans and Bonds, Equities, Money Market Instruments and Property. In so doing, it served to help finance a large number of major government as well as private sector projects that have contributed towards shaping the nation's development. More recently, it has had to look at suitable investment options outside of the country, as the local capital and money markets have not kept pace with the growth of EPF's assets (Employees Provident Fund 2013, 3; emphasis ours).

It is therefore probably no exaggeration to say that the EPF's importance to Malaysia's economy today is on a par with its importance to social security. 


\section{Conclusion}

In South Korea and Malaysia, contribution-based pension systemsalbeit organised in different ways-have become a cornerstone of economic development. Through the accumulation of large amounts of money within their pension systems, the governments of South Korea and Malaysia have been able to use this money for economic investments within their generally export-oriented economies, thus demonstrating that social policy and international economic interdependence are in fact mutually supportive. Whereas creating and expanding the pension scheme took place only within the last thirty years in South Korea, the Malaysian EPF, which emerged during the country's colonial period, celebrated its seventieths birthday. Moreover, although the dual function of serving both social and economic purposes was integral to the Korean pension scheme right from the start, in Malaysia the EPF was initially designed to provide welfare to workers. Only later did the country's government realise that the money could also be used to boost the national economy. Both pension schemes are currently experiencing considerable problems, especially when it comes to effective coverage rates and preventing poverty in old age. Nevertheless, the crucial role of the pension schemes in the countries' economic development makes a fundamental reorganisation of those schemes rather unlikely.

Acknowledgements This chapter is a product of the research conducted in the Collaborative Research Center "Global Dynamics of Social Policy" at the University of Bremen. The centre is funded by the Deutsche Forschungsgemeinschaft (DFG, German Research Foundation)—project number 374666841-SFB 1342.

\section{References}

Asher, Mukul G. 2012. Malaysia. Pension System Overview and Reform Directions. In Pension Systems and Old-Age Income Support in East and Southeast Asia. Overview and Reform Directions, ed. Donghyun Park, 101-123. London, New York: Routledge. 
Asher, Mukul, and Azad S. Bali. 2015. Public Pension Programs in Southeast Asia: An Assessment. Asian Economic Policy Review 10 (2): 225-245.

Choi, WoongBee, Jinkyu Lee, and Woo C. Kim. 2018. The Effect of Social Investment on the Sustainability of Korea National Pension Fund. SSRN Journal. https://doi.org/10.2139/ssrn.3179870.

Employees Provident Fund. 2013. Annual Report 2012. Retrieved July 15, 2020, from https://www.kwsp.gov.my/about-epf/news-highlights/publications.

. 2019. Annual Report 2018. Retrieved June 19, 2020, from https:// www.kwsp.gov.my/about-epf/news-highlights/publications.

Evans, Peter B., and Patrick Heller. 2015. Human Development, State Transformation, and the Politics of the Developmental State. In The Oxford Handbook of Transformations of the State, ed. Stephan Leibfried, Evelyne Huber, Matthew Lange, Jonah D. Levy, Frank Nullmeier, and John D. Stephens, 691-713. Oxford: Oxford University Press.

Hujo, Katja, and Sara Cook. 2012. The Political Economy of Social Pension Reform in Asia. In Social Protection for Older Persons. Social Pensions in Asia, ed. Sri W. Handayani and Babken Babajanian, 11-59. Mandaluyong City, Philippines: Asian Development Bank.

Hwang, Gyu-Jin. 2006. Pathways to State Welfare in Korea: Interests, Ideas and Institutions. Aldershot: Ashgate.

Kim, Won S., and Young J. Choi. 2014. Revisiting the Role of Bureaucrats in Pension Policy-Making: The Case of South Korea. Government and Opposition 49 (2): 264-289.

McKinnon, Roddy. 1996. The Public Management of National Provident Funds for State-Led Development. The Case of Malaysia's Employees' Provident Fund. International Journal of Public Sector Management 9 (1): 44-60.

Moon, Hyungpyo. 2012. Matching Contributions and Compliance in Korea's National Pension Program. In Matching Contributions for Pensions: A Review of International Experience, ed. Richard Hinz, Robert Holzmann, David Tuesta, and Noriyuki Takayama, 161-176. Washington, D.C.: The World Bank.

Effectiveness of the Matching Contribution Subsidy. In Social Policies in an Age of Austerity: A Comparative Analysis of the US and Korea, ed. John K. Scholz, Hyungpyo Moon, and Sang-Hyop Lee, 137-161. Cheltenham, UK: Edward Elgar Publishing.

National Pension Service. 2020. NPF at a Glance. Retrieved June 09, 2020, from https://fund.nps.or.kr/jsppage/fund/mcs_e/mcs_e_08_01.jsp. 
OECD. 2019. Pensions at a Glance 2019: OECD and G20 Indicators. Paris: OECD Publishing.

Peng, Ito. 2012. Economic Dualization in Japan and South Korea. In The Age of Dualization. The Changing Face of Inequality in Deindustrializing Societies, ed. Patrick Emmenegger, Silja Häusermann, Bruno Palier, and Martin SeeleibKaiser, 226-249. Oxford, New York: Oxford University Press.

Price, William J., Muhammed A. Khalif, Jose de Luna-Martinez, Wei Zhang, and Ashraf B. Arshad. 2018. Case Study on the Employees Provident Fund of Malaysia, The Malaysia Development Experience Series. Washington, D.C.: World Bank Group.

Ramesh, M. 2005. One and a Half Cheers for Provident Funds in Malaysia and Singapore. In Transforming the Developmental Welfare State in East Asia, ed. Huck-ju Kwon, 191-208. Basingstoke: Palgrave Macmillan.

Yang, Jae-jin. 2017. The Political Economy of the Small Welfare State in South Korea. New York: Cambridge University Press.

Yoo, Gyeongjoon, Changhui Kang, and Paul Choi. 2016. Measuring the Effects of a Social Insurances Subsidy Program (Duru-Nuri Program). The Korean Journal of Economic Studies 64 (1): 73-106.

Young, Jun I., Yoo H. Won, and Han S. Sil. 2016. Expanding Coverage of the National Pension Scheme to Young People. National Pension Service, Research Paper Summary. Retrieved August 13, 2019, from https://english.nps.or.kr/ jsppage/english/research/research_01.jsp. 
Open Access This chapter is licensed under the terms of the Creative Commons Attribution 4.0 International License (http://creativecommons.org/licenses/ by/4.0/), which permits use, sharing, adaptation, distribution and reproduction in any medium or format, as long as you give appropriate credit to the original author(s) and the source, provide a link to the Creative Commons licence and indicate if changes were made.

The images or other third party material in this chapter are included in the chapter's Creative Commons licence, unless indicated otherwise in a credit line to the material. If material is not included in the chapter's Creative Commons licence and your intended use is not permitted by statutory regulation or exceeds the permitted use, you will need to obtain permission directly from the copyright holder.

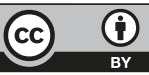

